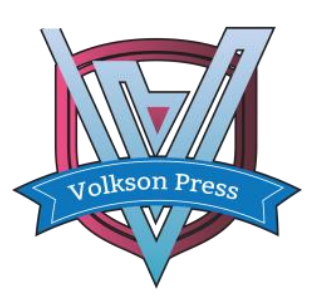

Contents List available at VOLKSON PRESS

Economics \& Management Innovations(EMI)

DOI : http://doi.org/10.26480/icemi.01.2017.103.105

\title{
Export Market Diversification and Innovation Capability of Chinese Firms: the Moderating Effect of Export Product Diversification
}

\author{
Rongkang Ma ${ }^{*}$, Xiangru Yao and Fengchao Liu \\ Dalian University of Technology, Linggong Road 2, High-tech District, Dalian, China \\ *email: marongkang@foxmail.com \\ This is an open access article distributed under the Creative Commons Attribution License, which permits unrestricted use, distribution, and reproduction in any \\ medium, provided the original work is properly cited.
}

\section{ARTICLE DETAILS}

\section{Article History:}

Received 02 october 2017 Accepted 06 october 2017

Available online 11 october 2017

\section{Keywords:}

Learning by exporting; export market diversification; export product diversification; innovation capability; Chinese firms

\section{ABSTRACT}

Taking advantage of the datasets of China Industrial Enterprises and China's Trade Statistics during 2004-2006, this paper examines the impact of export diversification strategy on Chinese firms' innovation capability, and explores different roles of export market diversification and export product diversification. The results show that, the degree of export market diversification has significant positive impact on Chinese firms' innovation capability. And the export product diversification positively moderates the relationship between the degree of export market diversification and Chinese firms' innovation capability. These findings have important implications for Chinese firms to implement export market and product diversification strategy, so as to enhance their innovation capability.

\section{Introduction}

International trade benefits the trading parties both in static terms through comparative advantage, and in dynamic terms through exposing countries to the knowledge stocks of their trading partners (Grossman \& Helpman, 1991). In practical terms, this 'learning by exporting' effect may be important at both the country level and at the level of the individual exporting firm.

On the macro level, ample theoretical and empirical research provides evidence that knowledge originating in one country increasingly transcends national boundaries and contributes to productivity growth and technological progress in other countries. But on the micro level, empirical studies of the effects of learning by exporting on firm performance have very mixed results (Wagner, 2007), and as Salomon \& Jin $(2008,2010)$ point out, to the extent that such firm-level learning exists, we still know relatively little about how different groups of firms learn from exporting.

Here, we are trying to look for evidence of learning by exporting amongst China's domestic manufacturing firms. According to China's import and export statistics, more than $75 \%$ of Chinese exporting firms are multiple product exporters, and meanwhile, more than $82 \%$ of Chinese exporting firms export to multiple international markets. So, The examination of firm export behavior in our study mainly from two aspects: export market diversification and export product diversification. Based on the literatures on learning by doing and internationalization diversification, this paper aims to reveal the relationship between export market diversification and innovation capability of Chinese firms, and also the moderating effect of export product diversification.

\section{Theory and hypotheses}

\subsection{Learning by exporting}

Exporting activity provides firms with at least two types of knowledgeknowledge about markets and knowledge about technology-which in turn form the basis for the development of further innovations and help improve performance (Salomon \& Shaver, 2005). Exporting firms may also benefit in terms of productivity and innovativeness in two other ways related to learning by exporting. First, the stronger competition in foreign markets forces firms to improve both products and processes and thus remain competitive. Second, scale effect may be important. Exporting extends the market over which margins may be earned, and since many costs, such as R\&D, are largely fixed, such investments may be recouped over a larger sales volume. This aids productivity, and provides greater incentives to invest in R\&D and innovation (Aw, Roberts \& Xu, 2008).

\subsection{Export market diversification and innovation capability}

According to the international diversification literatures, export market diversification can provide enterprises with a wide range of learning environment. First, enterprises with a high degree of diversification in the export market can access more diverse knowledge bases from different countries. Second, export market diversification enable enterprises to face differentiated business environment, so facilitating firms continue to innovation to customize their products, which could lead to enterprise the increase of innovation input. Finally, international diversification contributes to the realization of economies of scale, thus gaining rapid returns. Therefore, the following hypothesis is proposed:

H1: The degree of export market diversification is positively related with exporting firms' innovation capability.

\subsection{The moderating effect of export product diversification}

Diversification of export products act as the material basis for export market diversification. With the increase in the degree of export product diversification and the expansion of learning channels, enterprises can make better use of learning opportunities from export market diversification. First, the range of economies of scale brought about by the export product diversification will help reduce the cost pressures of diversification of export markets. Second, enterprises with export products diversification often have a diversified business structure, thus coping well with additional competitive pressures. Finally, when taking exporting products as channels to learn, the integration of knowledge of different products will help enterprises produce more innovation. Therefore, the following hypothesis is proposed:

H2: The diversification of export products has a positive moderating effect on the relationship between the degree of export market diversification 
and exporting firms' innovation capability.

\section{Data and Methods}

\subsection{Data}

To exploring the learning by exporting effect, the data that the empirical analysis used is collected mainly from two sources, the Chinese Annual Survey of Industrial Firms (CASIF) from the National Bureau of Statistics in China (NBS) for the innovation data and firm-level data, and the Chinese Customs Trade Statistics (CCTS) for the export data. When merging the two databases, the same way as Upward (2010) was taken - using firm name as the matching criteria to merge the two database. To ensure the continuity of the panel data, the merged database from 2004 to 2006 and the CASIF database of 2007 are used. Finally, the sample enterprises used for the study include 9514 in 2004, 11,171 in 2005, and 12,409 in 2006.

\subsection{Measurements}

Dependent variable-innovation capability (INO): The proportion of the new product output to a firm's total output is used to reflect firm's innovation capability. Based on the length of our panel, we use 1 year lag data.

Independent variable—export market diversification (EMD):

$$
\mathrm{EMD}=\sum_{i}\left[p_{i} \times \ln \left(1 / P_{i}\right)\right]
$$

Where $\mathrm{P}_{\mathrm{i}}$ is the proportion of exporting sales in international market $\mathrm{i}$ accounted for total export sales.

Moderate variable-export product diversification (EPD):

$$
\mathrm{EPD}=\sum_{m}\left[P_{m} \times \ln \left(1 / P_{m}\right)\right]
$$

Where $\mathrm{P}_{\mathrm{m}}$ is the proportion of exporting sales in product $\mathrm{m}$ accounted for total export sales.

Control variables: Firm age (AGE), firm size (SIZE), debt ratio (DEBT) and capital stock (CPT) are included as control variables.

\subsection{Method}

Given that the dependent variable, innovation output, measured as a ratio of new products output to total output, is continuous, and censored ranging from 0 to 1 . Meanwhile, many companies in the sample don't have any new products output, resulting in a zero being input for this variable. Accordingly, to account for this censoring as well as the continuous nature of the variable, Tobit model is used within Stata software.

\section{Results}

\begin{tabular}{|c|c|c|c|c|c|c|c|c|c|}
\hline $\begin{array}{l}\text { Varia } \\
\text { bles }\end{array}$ & $\begin{array}{l}\mathrm{Me} \\
\text { an }\end{array}$ & $\begin{array}{l}\text { S. } \\
\text { D. }\end{array}$ & INO & $\begin{array}{c}\text { EM } \\
\text { D }\end{array}$ & EPD & AGE & SIZE & $\begin{array}{l}\text { DE } \\
\text { BT }\end{array}$ & $\begin{array}{l}\mathrm{C} \\
\mathrm{P} \\
\mathrm{T}\end{array}$ \\
\hline INO & $\begin{array}{l}0.0 \\
83\end{array}$ & $\begin{array}{c}0 . \\
22\end{array}$ & 1 & & & & & & \\
\hline EMD & $\begin{array}{c}1.0 \\
4\end{array}$ & $\begin{array}{c}0 . \\
84\end{array}$ & $\begin{array}{c}0.06 \\
* * *\end{array}$ & 1 & & & & & \\
\hline EPD & $\begin{array}{c}0.5 \\
9\end{array}$ & $\begin{array}{c}0 . \\
62\end{array}$ & $\begin{array}{c}- \\
0.00 \\
1\end{array}$ & $\begin{array}{c}0.26 \\
* * *\end{array}$ & 1 & & & & \\
\hline AGE & $\begin{array}{c}9.6 \\
1\end{array}$ & $\begin{array}{c}9 . \\
87\end{array}$ & $\begin{array}{c}0.10 \\
* * *\end{array}$ & $\begin{array}{c}0.00 \\
1\end{array}$ & $\begin{array}{c}0.01 \\
*\end{array}$ & 1 & & & \\
\hline SIZE & $\begin{array}{c}5.2 \\
8\end{array}$ & $\begin{array}{c}1 . \\
08\end{array}$ & $\begin{array}{c}0.13 \\
* * *\end{array}$ & $\begin{array}{c}0.12 \\
* * *\end{array}$ & $\begin{array}{c}0.10 \\
* * *\end{array}$ & $\begin{array}{c}0.33 \\
* * *\end{array}$ & 1 & & \\
\hline DEBT & $\begin{array}{c}0.6 \\
1\end{array}$ & $\begin{array}{c}0 . \\
22\end{array}$ & $\begin{array}{c}- \\
0.04 \\
* * *\end{array}$ & $\begin{array}{c}0.03 \\
* * *\end{array}$ & $\begin{array}{c}0.03 \\
* * *\end{array}$ & $\begin{array}{c}0.03 \\
* * *\end{array}$ & $\begin{array}{c}0.07 \\
* * *\end{array}$ & 1 & \\
\hline CPT & $\begin{array}{c}5.0 \\
4\end{array}$ & $\begin{array}{c}0 . \\
99\end{array}$ & $\begin{array}{c}0.17 \\
* * *\end{array}$ & $\begin{array}{c}0.00 \\
4\end{array}$ & $\begin{array}{c}- \\
0.05 \\
* * * \\
\end{array}$ & $\begin{array}{c}0.12 \\
* * *\end{array}$ & $\begin{array}{c}- \\
0.06 \\
* * *\end{array}$ & $\begin{array}{c}- \\
0.0 \\
1 \\
\end{array}$ & 1 \\
\hline
\end{tabular}

Table 1 Descriptive statistics and correlation coefficients

Note: ${ }^{*} p<0.10, * * p<0.05, * * * p<0.01$

Table 1 presents the descriptive statistics and correlation coefficients. Observing the average value of each variable, the average enterprise innovation ability is 0.083 , namely the proportion of new product output to the enterprise total output is $8.3 \%$. The average export market diversification is 1.04. The average export product diversification is 0.59 . The correlation coefficient between every two variables is lower than 0.5 so the influence of multicollinearity can be eliminated and further regression analysis is allowed.

\begin{tabular}{|c|c|c|c|}
\hline Variables & Model 1 & Model 2 & Model 4 \\
\hline Constant & -2.03 & -2.03 & -2.05 \\
\hline \multirow[t]{2}{*}{ AGE } & $0.003^{* * *}$ & $0.003^{* * *}$ & $0.003^{* * *}$ \\
\hline & $(-0.001)$ & $(-0.001)$ & $(-0.001)$ \\
\hline \multirow[t]{2}{*}{ SIZE } & $0.119^{* * *}$ & $0.113^{* * *}$ & $0.113^{* * *}$ \\
\hline & $(-0.004)$ & $(-0.004)$ & $(-0.005)$ \\
\hline \multirow[t]{2}{*}{ DEBT } & $-0.114^{* * *}$ & $-0.116^{* * *}$ & $-0.117^{* * *}$ \\
\hline & $(-0.02)$ & $(-0.02)$ & $(-0.02)$ \\
\hline \multirow[t]{2}{*}{ СPT } & $0.126^{* * *}$ & $0.127^{* * *}$ & $0.127^{* * *}$ \\
\hline & $(-0.005)$ & $(-0.005)$ & $(-0.005)$ \\
\hline \multirow[t]{2}{*}{ SOE } & $0.055^{* * *}$ & $0.057^{* * *}$ & $0.056^{* * *}$ \\
\hline & $(-0.01)$ & $(-0.01)$ & $(-0.01)$ \\
\hline YEAR & Included & Included & Included \\
\hline REGION & Included & Included & Included \\
\hline INDUSTRY & Included & Included & Included \\
\hline \multirow[t]{2}{*}{ EMD } & $0.049^{* * *}$ & $0.047^{* * *}$ & $0.050^{* * *}$ \\
\hline & $(-0.005)$ & $(-0.005)$ & $(-0.005)$ \\
\hline \multirow[t]{2}{*}{ EPD } & & 0.009 & 0.002 \\
\hline & & $(-0.008)$ & $(-0.008)$ \\
\hline \multirow[t]{2}{*}{ EMD*EPD } & & & $0.021^{* *}$ \\
\hline & & & $(-0.009)$ \\
\hline $\mathrm{N}$ & 33094 & 33094 & 33094 \\
\hline $\begin{array}{c}\text { Log } \\
\text { likelihood }\end{array}$ & -14104.7 & -14059.9 & -14050 \\
\hline LR chi2 & $4050.6^{* * *}$ & $4140.3^{* * *}$ & $4160.1^{* * *}$ \\
\hline
\end{tabular}

Table 2 Regression results with Tobit model

Table 2 shows the regression results. Besides the control variables, Model 1 includes independent variable - export market diversification (EMD). The coefficient of EMD is significantly positive $(\beta=0.049, p<0.01)$, which means export market diversification has significant positive impact on firm innovation capability, which supports for H1. Model 2 includes moderate variables - export product diversification (EPD), and model 3 includes the interaction item of export market diversification (EMD) and export product diversification (EPD). The coefficient of EPD is insignificant, but the coeffient of the interaction item is significantly positive $(\beta=0.021$, $\mathrm{p}<0.05$ ), which means the export product diversification significantly positively moderates the relationship between the degree of export market diversification and exporting firms' innovation capability, thus supporting for $\mathrm{H} 2$.

\section{Conclusions}

Taking Chinese firms' exports from 2004 to 2006 as a research sample, this paper aims to investigate the impact of export diversification strategy on Chinese firms' innovation capability, and explores different roles of export market diversification and export product diversification. We find that, the degree of export market diversification has significant positive impact on Chinese firms' innovation capability. And the export product diversification positively moderates the relationship between the degree of export market diversification and Chinese firms' innovation capability. So, Chinese firms should take export market diversification strategy as much as possible, and export more kinds of products to different countries, thus enhancing the effects of learning by exporting.

\section{Acknowledgement}

The research is financially supported by the National Natural Science Foundation of China (71473026), the Humanities and Social Science Youth 
Foundation of Ministry of Education of China (15YJC630092), and China Postdoctoral Science Foundation (2015M571311).

\section{References}

[1] Grossman, G. M., \& Helpman, E. Trade, knowledge spillovers, and growth. European Economic Review, Vol. 35 (1991), p. 517-526.

[2] Wagner, J. Exports and productivity: A survey of the evidence from firm-level data. The World Economy, Vol. 30 (2007), p. 60-82.

[3] Salomon, R., \& Jin, B. Does knowledge spill to leaders or laggards? Exploring industry heterogeneity in learning by exporting. Journal of International Business Studies, Vol. 39 (2008), p. 132-150.
[4] Salomon, R., \& Jin, B. Do leading or lagging firms learn more from exporting? Strategic Management Journal, Vol. 31 (2010), p. 10881113.

[5] Salomon, R., \& Shaver, J. M. Learning by exporting: New insights from examining firm innovation. Journal of Economics and Management Strategy, Vol. 14 (2005), p. 431-460.

[6] Aw, B. Y., Roberts, M. J., \& Xu, D. Y. R\&D investments, exporting, and the evolution of firm productivity. American Economic Review, Vol. 98 (2008), p. 451-456.

[7] Upward R, Wang Z, Zheng J. Weighing China's export basket: An account of the Chinese export boom, 2000-2007. GEP Research Paper, Vol. 14 (2010), p. 1-65. 